\title{
The Effects of Personal, Environmental, and Genetic Factors on Epidemic of Coronavirus Disease-19: A Review of the Current Literature
}

\author{
Salar Bakhtiyari ${ }^{1}$, Amin Mirzaei $^{2}$, Mohsen Jalilian $^{2}$, Sajad Mazlomi $^{3}$, Heshmatollah Nourmoradi ${ }^{3,4 *}$, Hojatollah Kakaei ${ }^{5}$ \\ ${ }^{1}$ Department of Clinical Biochemistry, School of Medicine, Ilam University of Medical Sciences, Ilam, Iran; ${ }^{2}$ Department of Public \\ Health, School of Health, Ilam University of Medical Sciences, Ilam, Iran; ${ }^{3}$ Department of Environmental Health Engineering, \\ School of Health, Ilam University of Medical Sciences, Ilam, Iran; ${ }^{4}$ Biotechnology and Medicinal Plant Research Center, Ilam \\ University of Medical Sciences, Ilam, Iran; ${ }^{5}$ Department of Occupational Health Engineering, School of Health, Ilam University \\ of Medical Sciences, Ilam, Iran
}

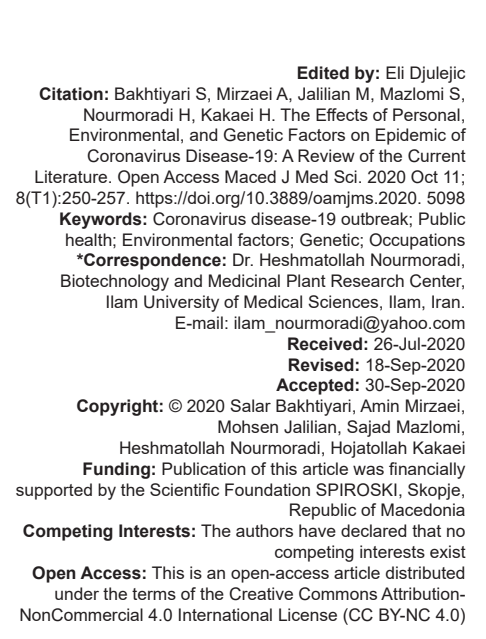

\begin{abstract}
Coronavirus disease (COVID)-19 is a viral disease that broke out in late 2019 in Wuhan, China. The World Health Organization has been forced to declare a public health emergency due to the global outbreak of COVID-19. The concerns about the COVID-19 disease are the rapid increase in the number of patients as well as the number of deaths compared with severe acute respiratory syndrome disease. Given that there is a remarkable variability amongst people for COVID-19 infection, there really is the possibility that there will be genetic and environmental effects, it is a need for their role to be fully clarified as soon as possible. Numerous studies have been performed on the on the stability of COVID-19 virus in different environmental conditions including temperature and humidity. In this study, we aimed to discuss in detail the benefits and effects of these factors on COVID-19. Some studies have confirmed the relationship between environmental conditions and disease transmission and others have rejected. Furthermore, not all COVID-19 exposed people are infected and not all infected patients develop severe respiratory complications. It is quite likely that these disparities are genetically mediated, in part. People who may be occupationally exposed to this virus may be due to different reasons, including lack of health, lack of knowledge and attitude, and working conditions. Reducing human-to-human contact by increasing the level of public health in the community as well as maintaining social distance plays a key role in prevention of COVID-19 disease. However many aspects of COVID-19 are still unknown and require further and extensive studies.
\end{abstract}

\section{Introduction}

In December 2019, in Wuhan, China, a virus was first identified that was named Coronavirus (CoV) Disease (COVID)-19 because it was caused by the severe acute respiratory syndrome (SARS)-CoV-2 virus. The World Health Organization (WHO) Director-General announced on January 30,2020, that the outbreak of COVID-19 is a global concern [1], [2], [3]\{Sohrabi, $2020 \# 1$ \}. Evidence recommends that COVID-19 is mainly transmitted through close contact with infected individuals through bodily secretions including nasal fluid, saliva, and respiratory droplets spread by speaking, sneezing or coughing [2], [4], [5]. The most commonly reported symptoms of the disease include fever, dry cough and fatigue, and in fewer frequent cases, headaches, diarrhea, shortness of breath, and sore throat [5], [6], [7], [8], [9].

\section{Study Strategy}

The compilation of this review study was carried out in April 2020. To find the related published papers on the effect of personal and environmental conditions and genetics on COVID-19, the recent electronic documents from Google, PubMed, Google scholar, Elsevier, and Scopus were applied. Various key words, including COVID-19, environmental condition (air temperature and humidity), water, wastewater, solid waste, food, genetics, personal health, occupations, and disinfection, were used to investigate the study.

\section{Epidemiologic Characteristics of the COVID-19}

The WHO report no108 on COVID-19 global situation on June 14, 2020, was demonstrated that 216 
countries had reported confirmed COVID-19 morbidity. At the time of the report, the total number of cases and death were $27,486,960$ and 894,983, respectively [10].

$\mathrm{CoV}$ is a single-stranded RNA virus resembling a crown under electron microscopy (due to the presence of spike glycoproteins on the envelope), which is divided into four genres including alpha, beta, gamma, and delta CoV. The SARS-CoV and SARS-CoV-2 (COVID-19) genomes have about $80 \%$ identity and belong to the beta genre and cause symptoms such as fever, malaise, dry cough, and acute respiratory response [11]. This newly discovered CoV is associated with the recent outbreak of pneumonia in humans and probable bat origin [12].

The diameter of COVID-19 is around 60-140 $\mathrm{nm}$ and has a spherical or oval and often pleomorphic form. It is sensitive to heat and ultraviolet rays like other CoVs. In addition, using lipid solvents including ethanol, ether (75\%), chlorine-containing disinfectant, chloroform, and peroxyacetic acid, this virus can be effectively eliminated [13].

The median incubation period of COVID-19 from exposure to the first symptoms was reported in Qian et al., Xu et al., Guan et al., and Singhal studies for 3, 4, 4, and 5 days, respectively [6], [7], [8], [14]. Symptoms in most people are mild and, in some cases (often elderly), the symptoms are severe and it is also asymptomatic in most people [8]. The median age of patients was reported in studies of Xu et al., Sun et al., and Guan et al., studies were reported 41,46 , and 47 years, respectively.

The overall case-fatality rate has been reported at between $2 \%$ and $3.4 \%$ [8], [11], [12], [15]. Mortality is higher in the elderly and in cardiovascular, diabetic, cancerous, or chronic respiratory patients and is very low in children [3], [15]. Although the fatality rate of COVID-19 is lower than its two ancestors the SARS-CoV and Middle East respiratory syndrome CoV (MERS-CoV); however, it is much faster to spread [8]. Estimates of contagiousness of COVID-19 $\left(R_{0}\right)$ has been reported in some studies ranging from 1.5 to 5.2 [5], [16], [17]. $R_{0}$ is defined as "the average number of people who will contract a disease from one contagious person" [5], [18]. However, within the closed environments as well as in high-density environments such as hospitals, where contact between people is getting closer, the $R_{0}$ of COVID-19 has been estimated to be significantly higher (estimates ranging from 5 to 14) [5], [19], [20], [21]. However, with the enhancement of healthcare and increasing public health in the community, the $\mathrm{R}_{0}$ will decline [17].

\section{Genetic Susceptibility to COVID-19 Infection}

In the case of COVID-19, what is controversial for researchers and clinicians is that not all COVID-19 exposed people are infected and not all infected patients develop severe respiratory complications. Although the exact mechanisms behind these dramatically different infection outcomes remain to be elucidated, it is quite likely that these disparities are genetically mediated, in part [22].

For entering into the host cells, many viruses use multiple alternative receptors. The study by $\mathrm{Lu}$ et al. showed that SARS-CoV and SARS-CoV-2 have similar receptor binding domain structures. Further studies showed that these viruses use the same receptor for entering the cells. This receptor is angiotensin-converting enzyme 2 (ACE2) and is involved in the pathogenicity of SARS-CoV and SARSCoV-2 [12], [23].

The previous studies have shown that the expression level of ACE2 is influenced by age, sex, and smoking. Thus, the pathogenicity of COVID-19 varies in different populations and races. Zhao et al. (preprint) showed the predominant expression of ACE2 in Asian men, which might be one of the possible reasons for the higher prevalence of COVID-19 in this subgroup of patients compared to the women and patients of other populations [24].

In a study of Asian and Caucasian people by Cai (preprint) was shown that there was not any significant difference in ACE2 expression between these groups. Furthermore, ACE2 expression was not affected by sex and age. However, it was significantly higher in smokers than non-smokers of Asian ethnicity [25]. Some studies reported that there was no significant relationship between smoking and the prevalence or severity of COVID-19 [7], [26].

In a study on critically ill patients with COVID19 by Yang et al., it was found that more men were affected (67\%) than women [27]. Of the 1099 patients with COVID-19 hospitalized in 30 hospitals in China, $58 \%$ were reported to be men [7]. In contrast, one study of 140 patients with COVID-19 reported the equal sex distribution [26].

Different immune responses to pathogens can be due to genetic differences between individuals. When the immune system is compromised, the SARSCoA-2 can spread in the body and cause extensive damage to tissues that have high expression of the ACE2 gene such as the lung, intestine, and kidney. Innate inflammation that is largely mediated by proinflammatory macrophages and granulocytes is induced by the lung damaged cells. Lung inflammation is the main complication of COVID-19 infection at the severe stage [28]. Accordingly, it is very critical to identify human leukocyte antigen (HLA) molecules that have increased binding specificities for peptides of SARS-CoV-2 presented on the antigen-presenting cell surface. Given that there are no related data available so far, we can obtain some information from the work of researchers on SARS-CoV. Several studies have shown 
the association between HLA polymorphisms and the susceptibility of SARS-CoV, such as HLA-DRB1*1202, HLA-B*0703, HLA-B*4601 [29], and HLA-Cw*0801 [30] and some polymorphisms related to the protection from SARS infection including HLA-A*0201, HLA-Cw1502, and HLA-DR0301 alleles [31]. This information will be very advantageous for the treatment of COVID19. Together, to identify the mechanism of COVID19 pathogenicity and the environmental and genetic factors affecting the prevalence and severity of the disease, many studies should be conducted in different populations and races around the world to determine the effects of age, sex, genetic background, and environmental factors on this disease.

\section{The Effect of Environmental Condition (Temperature AND Humidity) on Spread of COVID-19}

Several studies have been conducted on the effects of environmental conditions such as ambient temperature and humidity on the stability of the COVID19 virus. Some of these researches have considered the association between the environmental factors to be effective, and other studies have not found a relationship between these factors and COVID-19 virus transmission and spread. Wang et al. (2020) concluded that environmental conditions such as humidity and air temperature play an important role in the spread of disease. Based on this study, the prevalence of the disease was higher in countries with the lower humidity and temperature (Iran and South Korea) than other countries with higher humidity and temperature (Singapore and Thailand) [32]. This finding can due to the high viral stability in the cold weather and the susceptibility of the host immune system to cold air and low humidity [32]. There was also such a trend for the SARS virus [33].

Sajadi et al. study (2020) showed that COVID19 morbidity will decrease in countries above $30^{\circ} \mathrm{C}$ during the coming months and summer due to rising temperatures. The disease in the tropics may also cause seasonal peaks and in the southern hemisphere may cause outbreaks in the months ahead. In temperate regions, it may lead to outbreaks in late fall and winter. Extensive health care can prevent summer outbreaks in the tropical and southern hemisphere [34].

Wang et al. (2020) study on the effect of ambient temperature on the COVID-19 disease transmission in 34 Chinese provinces and 26 countries showed that ambient temperature had significant effects on the disease transmission rate. The study indicated that by reducing the air temperature, the transmission of the disease was increased. According to this study, when the air temperature reaches $30^{\circ} \mathrm{C}$, the cumulative number of cases increases by only 3.38, indicating that the COVID-19 virus is sensitive to ambient temperature [35]. There is also a pattern in the spread of other viral diseases, such as the flu. The prevalence of influenza is high from May to September in the Southern Hemisphere and November to March in the Northern Hemisphere where temperatures are low [36]. Other studies have also shown that the prevalence of swine flu is also increased at low air temperature and humidity [37]. Studies on SARS disease also showed that increasing air temperature and humidity from 22 to $25^{\circ} \mathrm{C}$ and $40-50 \%$ to $38^{\circ} \mathrm{C}$ and $95 \%$, increase the activity of the virus on the surfaces from 5 days to near zero, respectively [33]. In other studies, it was proved that low temperature and humidity had a significant effect on the survival rate of other CoVs, such as MERS [38]. In a study by Bu et al. (2020) on the effect of air temperature and humidity on the COVID-19 virus, it was found that temperatures of $13-19^{\circ} \mathrm{C}$ and humidity of $50-80 \%$ were considered as suitable conditions for survival and spread of the disease [39]. Oliveiros et al. (2020) on the effect of ambient temperature and humidity on COVID-19 concluded that doubling time was directly and inversely correlated with ambient temperature and humidity, respectively [40]. For this reason, the spread of the disease is expected to slow in the spring and summer of the northern hemisphere. It is also expected that by $20^{\circ} \mathrm{C}$ increasing the air temperature, the doubling time will be delayed to 1.8 days. These factors account for $18 \%$ of the variation in disease doubling time. The other $82 \%$ may be connected to personal health measures, population bulk, commuting, and people's customs [40]. Other studies have shown that environmental conditions including temperature and humidity alone do not essentially result in decreasing the number of COVID-19 cases without rigid health interventions [41]. In the study by Cai et al. (2020), we reported that there was no relationship between daily ambient temperature and growth rate of COVID19 epidemic [42]. Poirier et al. (2020) stated that high humidity and temperature did not diminish the spread and survival of COVID-19 virus. According to a study conducted in China, Iran, Italy, Japan, and South Korea, the environmental conditions (temperature and humidity) did not appear to affect the number of COVID19 cases [43]. It seems more extensive studies are needed to prove the effects of environmental conditions (temperature and humidity) on the stability and spread of COVID-19 virus.

\section{The Effect of Water, Wastewater, Solid Waste, and Food on Spread of COVID-19}

The risks of COVID-19 transmission through human wastewater (feces) are very low. However, 
scientific studies have confirmed the presence of viral RNA fragments in human feces [44], [45] and in a study using virus culture from the human stool, viral RNA has also been detected[46]. However, so far, no studies have confirmed the oral-fecal transmission of the virus [47]. In the wastewater containing COVID-19 virus, wastewater treatment plants (especially in the disinfection part) effectively inactivate the virus [48]. Washing hands with soap and water for at least $20 \mathrm{~s}$ is a necessity if contact with the stools of suspected or ill persons occurs. Washing hands with soap and water for at least $20 \mathrm{~s}$ is sufficient if contact with the stools of suspected or ill persons. Furthermore, given that the feces of COVID-19 persons are considered as biohazard, the people responsible for stool disposal, especially in hospitals, should be provided with masks, gloves, and protective equipment [47]. The COVID-19 virus is a virus with a fragile outer membrane. Membrane viruses are usually low resistant to environmental conditions, especially disinfectants such as chlorine and ozone. The inactivation time of membrane viruses is much lower than of non-membrane viruses [47]. While the presence of virus in drinking water is possible, no studies have been conducted on the presence and transmission of COVID-19 virus in surface and ground waters. As sodium hypochlorite solution can inactivate COVID-19 virus on the surfaces, it seems that in drinking water containing disinfectants, the virus inactivation can rapidly occur. For this reason, the risk of virus transmission through drinking water is very low. Operational measures including water disinfection and proper storage in clean containers can be helpful to prevent virus transmission from contaminated water. For effective disinfection of drinking water containing the virus, it is recommended that the chlorine concentration should be $\geq 0.5 \mathrm{mg} / \mathrm{L}$ with a minimum contact time of $30 \mathrm{~min}$ and $\mathrm{a} \mathrm{pH}$ of $<8$ [49]. If treated drinking water is unavailable, household water purifiers with nanofilter, ultrafilter and reverse osmosis membranes or ultraviolet radiation can be effective to inactivate the virus. Water boiling and solar radiation can also remove the virus from potable water [47].

Hospital waste management plays a key role in the control of the COVID-19 epidemic and includes separation, collection, and disposal [50]. Hospital waste management should be healthily conducted. The absence of proper management at each stage can result in developing the disease among staff, patients, and also people. The waste generated in the COVID-19 patient's wards should be considered as highly infectious. For this reason, separation is not required for disposing of COVID-19 patient's waste and should be considered as completely infectious. These wastes should be collected in lid standards containers. Hospital waste management workers should be fully equipped with glove, hat, gown, boot, and face shield (mask). The waste collection period at COVID-19 patients' wards was daily ( $24 \mathrm{~h})$ carried out in China during the disease epidemic time [51]. One of the best ways for the disposal of hospital wastes to prevent the release of COVID-19 virus is incinerators which have a great role in the destruction of biological agents [51]. According to a study by Rafiee et al. (2016) on hospital waste management, the use of hydroclave, as well as autoclave, has been suggested as two suitable options for the control of waste infection [52]. So far, no study has been reported on the transmission of COVID-19 virus by hospital wastes [47]. Epidemiological evidence suggests that the zoonotic transmission of the virus occurred in December 2019 at the Wuhan's Huanan Wildlife Market. Molecular researches have also reported that the COVID-19 virus is very similar to the $\mathrm{CoV}$ isolated from the horseshoe bat [53]. Therefore, the zoonotic transmission of the virus from animals to humans is possible. Unlike other foodborne viruses such as norovirus and hepatitis $A$ that causes foodborne viral gastroenteritis, COVID-19 virus causes severe respiratory infection. It has been no documents about the food-borne transmission of COVID-19 [54].

\section{COVID-19 and Occupations}

In addition to healthcare workers, a large number of people in various professions including industry, agriculture, public services, traffic police, staff public transport, and taxi drivers are at risk for COVD-19 [55], [56], [57], [58]. In 2018, the Bureau of Labor Statistics (BLS) estimated the total number of employees in the United States at 144.7 million. Of these, $18.4 \%(26.669 .810)$ at least once a month and $10 \%(14.425 .070)$ at least once a week are exposed to the pathogen [59], [60]. There are 150 million international migrant workers worldwide. About 95\% of them are resident in the five $\mathrm{WHO}$ regions where COVID-19 has been confirmed [61]. The employment rate for 2018 in the Central and West Asia region was $58.3 \%$ [62].

To reduce the prevalence of COVID-19 in businesses, workers, and the general public, it is important that all employers plan to counter COVID19. The amount of occupational exposure risk depends largely on the type of industry; however, to help employers, Occupational Safety and Health Administration (OSHA) has divided job duties into four levels of risk: Very high-risk, high-risk, medium-risk, and low-risk. Most American workers are likely to be at low or medium exposure levels. In the very high-risk group is occupation such as healthcare workers (e.g., doctors, nurses, paramedics, sampling laboratories, and morgue staff performing autopsies). The high-risk group includes occupations such as healthcare and support staff (people who need to enter the patient room), medical transport staff (ambulance operator), and cold storage staff involved in preparing the bodies 
of suspected COVID-19. In the middle-risk group is that who need frequent or close contact (e.g., less than 6 feet) with people who may be infected with COVID-19 (Staff with international jobs). Finally, there are lowrisk (precautionary) groups in the business that have the least amount of job contact with people and other colleagues [63].

Since the transmission features of COVID-19 have not yet been fully identified, the WHO recommends wearing masks for all occupations in public and crowded environments [64], [65], [66], [67]. Although no study to date has compared the efficacy of N95 masks and surgical masks in preventing influenza or other respiratory infections in healthcare workers, almost all practitioners recommend the use of N95 masks to protect against droplet transmission from coughs and sneezes of COVID-19 patients [68]

\section{Basic Approaches for the Prevention and Control of COVID-19 Disease}

The reviewed studies generally suggest two main approaches for preventing and controlling COVID19 , including promoting public health and maintaining social distance [2], [3], [5], [16], [69]. Preventive measures should be taken by everyone everywhere, including homes, workplaces, hospitals, schools, universities, shopping centers, mosques, churches, and temples. [2], [4], [5], [16], [70].

Quarantine is a very important strategy to prevent infected individuals from contacting healthy people, especially in the early stages of COVID-19 disease. The results of past studies point to the high significance of quarantine in cutting off the COVID-19 disease transmission chain. Accordingly, solutions such as quarantine travelers, who enter the country from high-risk areas, banning intercity travel and restricting intercity movement, closing or postponing school activities, churches, mosques, and workplaces, can be very effective in preventing and controlling of COVID19 disease [2], [3], [5], [16], [70], [71].

\section{Effect of Disinfectants on COVID-19 Virus}

Detailed information about the level of resistance of COVID-19 in the environment is not available, but it seems to behave like other CoVs [72]. Recent studies have shown that the resistance of human CoVs such as SARS-CoV, MERS, and other endemic human $\mathrm{CoV}$, is varied in different surfaces (from $2 \mathrm{~h}$ to 9 days) [72], [73]. The survival time of these viruses is affected by many factors such as surface structure, temperature, relative humidity, and type of virus species so that on inanimate surfaces such as metals, glass, and plastics can survive up to 9 days [72], [73].

Unfortunately, there is little information about the suitable disinfectant for confrontation to COVID-19. However, experts believe that effective disinfectants on other CoVs can also be effective to inactivate COVID-19 virus. There is a wide range of disinfectants for surface disinfection. Ethanol $62-71 \%$, hydrogenperoxide $0.5 \%$, and sodium hypochlorite $0.1 \%$ can effectively disable the CoVs during $1 \mathrm{~min}$ [74]. The WHO believes that a wide range of disinfectants is effective for enveloped viruses such as COVID-19 virus. At present, 70\% ethyl alcohol recommends for disinfection of small areas between uses such as reusable equipment (e.g., thermometer). Sodium hypochlorite at $0.5 \%$ (equivalent $5000 \mathrm{ppm}$ ) is recommended for disinfection of surfaces [72].

The efficiency of other disinfectants such as $\quad 0.05-0.2 \%$ benzalkoniumchloride or $0.02 \%$ chlorhexidinedigluconate was negligible [74]. Ultraviolet (UV)-C has a high ability to deactivate viruses, bacteria, and fungi in an aerosolized form [73]. A study showed that irradiation with UV for 60 min on several CoVs that were cultivated on the medium resulted in a lack of viral growth [74]. Quaternary ammonium compounds are able to remove the odor and have extensive biocidal and sporostatic activities [73]. To wash the clothes, the washing machine contains laundry detergent with a temperature of $60-90^{\circ} \mathrm{C}$ is recommended. If this is not possible, immerse the clothes in warm soapy water in a large container and use a stick to stir. After the drain of water and soap, it will be submerged in $0.05 \%$ chlorine for 30 min then drain, rinse, and dry in sunlight [47]. Ambulances and vehicles for the transport of suspicious cases should be cleaned and disinfected properly. For washing and disinfection, it should be cleaned first by household soap or detergent and then performed by $0.5 \%$ sodium hypochlorite as a disinfectant [75].

\section{Conclusion}

COVID 2019 is a pandemic with very high transmission power. Several studies have been conducted on the effect of genetic and environmental factors (temperature and humidity) on COVID19 transmission rate. Some of these studies have confirmed the relationship between environmental conditions and disease transmission and others have rejected. It seems more widespread studies are needed to prove the effects of factors on the stability and spread of COVID-19 virus. Not all COVID-19 exposed people are infected and not all infected patients develop severe respiratory complications. 
It is quite likely that these disparities are genetically mediated, in part. Because SARS-CoV-2 enters the cells through ACE2, by examining more cases from different genetic backgrounds and ethnicity and worldwide, ACE2 expression variation can be precisely analyzed and compared to establish whether it contributes to susceptibility to COVID-19 across the different subgroups. The number of people due to the occupation may be exposed to this virus are very high and, in many cases, may be due to different reasons, including lack of health, lack of knowledge and attitude, working conditions, and different safety culture. Reducing human-to-human contact by increasing the level of public health in the community as well as maintaining social distance plays a key role in prevention and control of COVID-19 disease. However, many aspects of Covid-19 are still unknown and require further and extensive studies.

\section{Acknowledgment}

The authors would like to thank Dr. Karimeh Haghani for constructive criticism of the manuscript.

\section{References}

1. Sohrabi C, Alsafi Z, O'Neill N, Khan M, Kerwan A, Al-Jabir A, et al. World Health Organization declares global emergency: A review of the 2019 novel coronavirus (COVID-19). Int J Surg. 2020;76:71-6. https://doi.org/10.1016/j.ijsu.2020.03.036

PMid:32112977

2. Organization WH. Rational Use of Personal Protective Equipment for Coronavirus Disease (COVID-19): Interim Guidance. Geneva: World Health Organization; 2020.

3. Sun P, Lu X, Xu C, Sun W, Pan B. Understanding of COVID19 based on current evidence. J Med Virol. 2020;92(6):548-51. https://doi.org/10.1002/jmv.25722 PMid:32096567

4. Li JP, Lam DS, Chen Y, Ting DS. Novel Coronavirus disease 2019 (COVID-19): The importance of recognising possible early ocular manifestation and using protective eyewear. $\mathrm{Br}$ J Ophthalmol. 2020;104(3):297-8. https://doi.org/10.1136/ bjophthalmol-2020-315994

PMid:32086236

5. Dietz L, Horve PF, Coil D, Fretz M, Van Den Wymelenberg K. 2019 novel coronavirus (COVID-19) pandemic: Built environment considerations to reduce transmission. mSystems. 2020;5(2):e00245-20. https://doi.org/10.1128/ msystems.00245-20

PMid:32265315

6. $\mathrm{Xu} X \mathrm{X}, \mathrm{Wu} \mathrm{XX}$, Jiang $\mathrm{XG}, \mathrm{Xu} \mathrm{KJ}$, Ying LJ, Ma $\mathrm{CL}$, et al. Clinical findings in a group of patients infected with the 2019 novel coronavirus (SARS-Cov-2) outside of Wuhan, China: Retrospective case series. BMJ. 2020;368:m792. https://doi. org/10.1136/bmj.m792

\section{PMid:32107200}

7. Guan WJ, Ni ZY, Hu Y, Liang WH, Ou CQ, He JX, et al. Clinical characteristics of coronavirus disease 2019 in China. N Engl J Med. 2020;382(18):1708-20.

8. Singhal T. A review of coronavirus disease-2019 (COVID-19). Indian J Pediatr. 2020;87(4):281-6.

PMid:32166607

9. Jiang F, Deng L, Zhang L, Cai Y, Cheung CW, Xia Z. Review of the clinical characteristics of coronavirus disease 2019 (COVID19). J Gen Intern Med. 2020;35(5):1545-9.

PMid:32133578

10. World Health Organization. Coronavirus Disease (COVID19): Weekly Epidemiological Update. Geneva: World Health Organization; 2020.

11. Huang $\mathrm{C}$, Wang $\mathrm{Y}$, Li X, Ren L, Zhao J, Hu Y, et al. Clinical features of patients infected with 2019 novel coronavirus in Wuhan, China. Lancet. 2020;395(10223):497-506. https://doi. org/10.1016/s0140-6736(20)30183-5

PMid:31986264

12. Li W, Moore MJ, Vasilieva N, Sui J, Wong SK, Berne MA, et al. Angiotensin-converting enzyme 2 is a functional receptor for the SARS coronavirus. Nature. 2003;426(6965):450-4. https://doi. org/10.1038/nature02145

PMid:14647384

13. Cascella M, Rajnik M, Cuomo A, Dulebohn SC, Napoli DR Features, Evaluation and Treatment Coronavirus (COVID-19). Treasure Island, FL: StatPearls Publishing; 2020.

14. Qian GQ, Yang NB, Ding F, Ma AH, Wang ZY, Shen YF, et al Epidemiologic and Clinical Characteristics of 91 Hospitalized Patients with COVID-19 in Zhejiang, China: A retrospective, multi-centre case series. QJM. 2020;113(7):474-81. https://doi. org/10.1093/qjmed/hcaa089

PMid:32181807

15. Wu Z, McGoogan JM. Characteristics of and important lessons from the coronavirus disease 2019 (COVID-19) outbreak in China: Summary of a report of 72314 cases from the Chinese Center for Disease Control and Prevention. JAMA. 2020;323(13):1239-42. https://doi.org/10.1001/jama.2020.2648 PMid:32091533

16. Dalton $\mathrm{C}$, Corbett $\mathrm{S}$, Katelaris A. Pre-emptive low cost socia distancing and enhanced hygiene implemented before local COVID-19 transmission could decrease the number and severity of cases. Med J Aust. 2020;212(10):1. https://doi.org/10.2139/ ssrn. 3549276

17. Liu Y, Gayle AA, Wilder-Smith A, Rocklöv J. The reproductive number of COVID-19 is higher compared to SARS coronavirus. J Travel Med. 2020;27(2):taaa021. https://doi.org/10.1093/jtm/ taaa021

PMid:32052846

18. Poon LL, Peiris M. Emergence of a novel human coronavirus threatening human health. Nat Med. 2020;26(3):317-9. https:// doi.org/10.1038/s41591-020-0796-5 PMid:32108160

19. Mizumoto K, Chowell G. Transmission potential of the nove coronavirus (COVID-19) onboard the Diamond Princess Cruises Ship. Infect Dis Model. 2020;5:264-70. https://doi. org/10.1101/2020.02.24.20027649

20. Zhao S, Cao P, Gao D, Zhuang Z, Chong MK, Cai Y, et al. Epidemic Growth and Reproduction Number for the Novel Coronavirus Disease (COVID-19) Outbreak on the Diamond Princess Cruise Ship from January 20 to February 19, 2020: A Preliminary Data-driven Analysis, Paper Statistics; 2020. https:// doi.org/10.2139/ssrn.3543150

21. Mizumoto K, Kagaya K, Zarebski A, Chowell G. Estimating the asymptomatic ratio of 2019 novel coronavirus 
onboard the princess cruises ship, Yokohama, Japan, 2020. Euro Surveill. 2020;25(10):2000180. https://doi. org/10.1101/2020.02.20.20025866

PMid:32183930

22. Shi Y, Wang Y, Shao C, Huang J, Gan J, Huang X, et al. COVID19 infection: The perspectives on immune responses. Cell Death Differ. 2020;27(5):1451-4. https://doi.org/10.1128/jvi.00127-20 PMid:32205856

23. Wan Y, Shang J, Graham R, Baric RS, Li F. Receptor recognition by the novel coronavirus from Wuhan: An analysis based on decade-long structural studies of SARS coronavirus. J Virol. 2020;94(7): e00127-20. https://doi.org/10.1128/JVI.00127-20 PMid: 31996437

24. Zhao Y, Zhao Z, Wang Y, Zhou Y, Ma Y, Zuo W. Singlecell RNA Expression Profiling of ACE2, the Putative Receptor of Wuhan 2019-nCov. BioRxiv; 2020. https://doi. org/10.1101/2020.01.26.919985

25. Cai G. Bulk and Single-cell Transcriptomics Identify Tobacco-use Disparity in Lung Gene Expression of ACE2, the Receptor of 2019-nCov. MedRxiv; 2020. https://doi. org/10.1101/2020.02.05.20020107

26. Zhang JJ, Dong X, Cao YY, Yuan YD, Yang YB, Yan YQ, et al. Clinical characteristics of 140 patients infected with SARSCoV-2 in Wuhan, China. Allergy. 2020;75(7):1730-41 PMid:32077115

27. Yang X, Yu Y, Xu J, Shu H, Liu H, Wu Y, et al. Clinical course and outcomes of critically ill patients with SARS-CoV-2 pneumonia in Wuhan, China: A single-centered, retrospective, observational study. Lancet Respir Med. 2020;8(5):475-81. https://doi. org/10.1016/s2213-2600(20)30079-5 PMid:32105632

28. Xu Z, Shi L, Wang Y, Zhang J, Huang L, Zhang C, etal. Pathological findings of COVID-19 associated with acute respiratory distress syndrome. Lancet Respir Med. 2020;8(4):420-2. https://doi. org/10.1016/s2213-2600(20)30076-x PMid:32085846

29. Keicho N, Itoyama S, Kashiwase K, Phi NC, Long HT, Van Ban V, et al. Association of human leukocyte antigen class II alleles with severe acute respiratory syndrome in the Vietnamese population. Hum Immunol. 2009;70(7):527-31. https://doi. org/10.1016/j.humimm.2009.05.006 PMid:19445991

30. Chen YM, Liang SY, Shih YP, Chen CY, Lee YM, Chang L, et al. Epidemiological and genetic correlates of severe acute respiratory syndrome coronavirus infection in the hospital with the highest nosocomial infection rate in Taiwan in 2003. J Clin Microbiol. 2006;44(2):359-65. https://doi.org/10.1128/ jcm.44.2.359-365.2006

PMid:16455884

31. Wang SF, Chen KH, Chen M, Li WY, Chen YJ, Tsao $\mathrm{CH}$, et al. Human-leukocyte antigen class I Cw 1502 and class II DR 0301 genotypes are associated with resistance to severe acute respiratory syndrome (SARS) infection. Viral Immunol. 2011;24(5):421-6. https://doi.org/10.1089/vim.2011.0024 PMid:21958371

32. Wang J, Tang K, Feng K, Lv W. High Temperature and High Humidity Reduce the Transmission of COVID-19, Paper Statistics; 2020. https://doi.org/10.2139/ssrn.3551767

33. Chan K, Peiris J, Lam S, Poon L, Yuen K, Seto W. The effects of temperature and relative humidity on the viability of the SARS coronavirus. Adv Virol. 2011;2011:734690. https://doi. org/10.1155/2011/734690

34. Sajadi MM, Habibzadeh P, Vintzileos A, Shokouhi S, MirallesWilhelm F, Amoroso A. Temperature, humidity, and latitude analysis to predict potential spread and seasonality for
COVID-19. JAMA Netw Open. 2020;3(6):e2011834. https://doi. org/10.2139/ssrn.3550308

PMid:32525550

35. Wang M, Jiang A, Gong L, Luo L, Guo W, Li C, et al. Temperature Significant Change COVID-19 Transmission in 429 Cities. MedRxiv; 2020.

36. Hemmes J, Winkler $\mathrm{K}$, Kool S. Virus survival as a seasonal factor in influenza and poliomyelitis. Antonie Van Leeuwenhoek. 1962;28(1):221-33. https://doi.org/10.1007/bf02538737 PMid:13953681

37. Lowen AC, Mubareka S, Steel J, Palese P. Influenza virus transmission is dependent on relative humidity and temperature. PLoS Pathog. 2007;3(10):1470-6. https://doi.org/10.1371/ journal.ppat.0030151

PMid:17953482

38. Van Doremalen N, Bushmaker T, Munster V. Stability of Middle East respiratory syndrome coronavirus (MERS-CoV) under different environmental conditions. Eurosurveillance. 2013;18(38):20590. https://doi.org/10.2807/1560-7917. es2013.18.38.20590 PMid:24084338

39. Bu J, Peng DD, Xiao H, Yue Q, Han Y, Lin Y, et al. Analysis of Meteorological Conditions and Prediction of Epidemic Trend of 2019-nCoV Infection in 2020. medRxiv; 2020. https://doi. org/10.1101/2020.02.13.20022715

40. Oliveiros B, Caramelo L, Ferreira NC, Caramelo F. Role of Temperature and Humidity in the Modulation of the Doubling Time of COVID-19 Cases. medRxiv; 2020. https://doi. org/10.1101/2020.03.05.20031872

41. Luo W, Majumder M, Liu D, Poirier C, Mandl K, Lipsitch M, et al. The Role of Absolute Humidity on Transmission Rates of the COVID-19 Outbreak. medRxiv; 2020. https://doi. org/10.1101/2020.02.12.20022467

42. Cai Y, Huang T, Liu X, Xu G. The Effects of "Fangcang, Huoshenshan, and Leishenshan" Makeshift Hospitals and Temperature on the Mortality of COVID-19. medRxiv; 2020. https://doi.org/10.1101/2020.02.26.20028472

43. Poirier C, Luo W, Majumder MS, Liu D, Mandl K, Mooring T, et al The role of environmental factors on transmission rates of the COVID-19 outbreak: An initial assessment in two spatial scales. SSRN. 2020;1:3552677. https://doi.org/10.2139/ssrn.3552677 PMid:32714106

44. Xiao F, Tang M, Zheng X, Li C, He J, Hong Z, et al. Evidence for Gastrointestinal Infection of SARS-CoV-2. medRxiv; 2020.

45. Holshue $\mathrm{ML}$, DeBolt $\mathrm{C}$, Lindquist $\mathrm{S}$, Lofy $\mathrm{KH}$, Wiesman J, Bruce $\mathrm{H}$, et al. First case of 2019 novel coronavirus in the United States. N Engl J Med. 2020;382(10):929-36. PMid:32004427

46. Zhang Y, Chen C, Zhu S, Shu C, Wang D, Song J, et al. Isolation of 2019-nCoV from a stool specimen of a laboratory-confirmed case of the coronavirus disease 2019 (COVID-19). China CDC Wkly. 2020;2(8):123-4. https://doi.org/10.46234/ccdcw2020.033

47. World Health Organization. Water, Sanitation, Hygiene and Waste Management for COVID-19: Technical Brief, 03 March 2020. Genva: World Health Organization; 2020.

48. US Environmental Protection Agency. Coronavirus and Drinking Water and Wastewater; 2020. Available from: https://www. epa.gov/coronavirus/coronavirus-and-drinking-water-andwastewater. [Last accessed on 2020 Mar 27]

49. World Health Organization. Guidelines for Drinking-water Quality: First Addendum. $4^{\text {th }}$ ed. Geneva: World Health Organization; 2017.

50. Awodele O, Adewoye AA, Oparah AC. Assessment of medical waste management in seven hospitals in Lagos, Nigeria. BMC Public Health. 2016;16(1):269. https://doi.org/10.1186/ 
s12889-016-2916-1

51. Yu H, Sun X, Solvang WD, Zhao X. Reverse logistics network design for effective management of medical waste in epidemic outbreaks: Insights from the coronavirus disease 2019 (COVID19) outbreak in Wuhan (China). Int J Environ Res Public Health. 2020;17(5):1770. https://doi.org/10.3390/ijerph17051770 PMid:32182811

52. Rafiee A, Yaghmaeian K, Hoseini M, Parmy S, Mahvi A, Yunesian $\mathrm{M}$, et al. Assessment and selection of the best treatment alternative for infectious waste by modified sustainability assessment of technologies methodology. J Environ Health Sci Eng. 2016;14(1):10. https://doi.org/10.1186/ s40201-016-0251-1

PMid:27239313

53. Murdoch DR, French NP. COVID-19: Another infectious disease emerging at the animal-human interface. $\mathrm{N} Z \mathrm{Z}$ Med $\mathrm{J}$ 2020;133(1510):12-5.

PMid:32078596

54. Food and Drug Administration. Food Safety and the Coronavirus Disease 2019 (COVID-19). United States: Food and Drug Administration; 2020.

55. Webster R, Liu R, Karimullina K, Hall I, Amlôt R, Rubin G. A systematic review of infectious illness Presenteeism: prevalence, reasons and risk factors. BMC Public Health. 2019;19(1):799. https://doi.org/10.1186/s12889-019-7138-x

56. Bergström G, Bodin L, Hagberg J, Aronsson G, Josephson M. Sickness presenteeism today, sickness absenteeism tomorrow? A prospective study on sickness presenteeism and future sickness absenteeism. J Occup Environ Med. 2009;51(6):62938. https://doi.org/10.1097/jom.0b013e3181a8281b PMid:19448572

57. Montano D. Chemical and biological work-related risks across occupations in Europe: A review. J Occup Med Toxicol. 2014;9(1):28. https://doi.org/10.1186/1745-6673-9-28 PMid:25071862

58. Doubleday A, Baker MG, Lavoué J, Siemiatycki J, Seixas NS. Estimating the population prevalence of traditional and novel occupational exposures in Federal Region X. Am J Ind Med. 2019;62(2):111-22. https://doi.org/10.1002/ajim.22931 PMid:30548877

59. U.S. Bureau of Labor Statistics. Occupational Employment Statistics. Available from: https://www.bls.gov/oes/home.htm. [Last accessed on 2020 Feb 25].

60. U.S. Bureau of Labor Statistics. 2010 SOC User Guide; 2010. Available from: https://www.bls.gov/soc/soc_2010_user_guide. pdf. [Last accessed on 2020 Feb 25].

61. Liem A, Wang C, Wariyanti Y, Latkin CA, Hall BJ. The neglected health of international migrant workers in the COVID-19 epidemic. Lancet Psychiatry. 2020;7(4):e20. https://doi. org/10.1016/s2215-0366(20)30076-6

PMid:32085842

62. Alazimi F, Bojar Z, Karbalaie N, Qadam FS, Hassnavand S, Akhbari S, et al. Statistics of the Ministry of Cooperatives, Labor and Social Welfare- 2018. Iran: Strategic Statistics and Information Center Ministry of Co-operation, Labor and Social Welfare; 2019. p. 381.

63. Occupational Safety and Health Administration. Guidance on Preparing Workplaces for COVID-19. United States:
Occupational Safety and Health Administration; 2020.

64. World Health Organization. Advice on the Use of Masks in the Community, during Home Care, and in Health Care Settings in the Context of COVID-19: Interim Guidance, 19 March 2020. Geneva: World Health Organization; 2020.

65. Teasdale E, Santer M, Geraghty AW, Little P, Yardley L. Public perceptions of non-pharmaceutical interventions for reducing transmission of respiratory infection: Systematic review and synthesis of qualitative studies. BMC Public Health. 2014;14(1):589. https://doi.org/10.1186/1471-2458-14-589 PMid:24920395

66. Bai Y, Yao L, Wei T, Tian F, Jin DY, Chen L, et al. Presumed asymptomatic carrier transmission of COVID-19. JAMA. 2020;323(14):1406-7. https://doi.org/10.1001/jama.2020.2565 PMid:32083643

67. Zou L, Ruan F, Huang M, Liang L, Huang H, Hong Z, et al. SARS-CoV-2 viral load in upper respiratory specimens of infected patients. N Engl J Med. 2020;382(12):1177-9. https:// doi.org/10.1056/nejmc2001737

PMid:32074444

68. Radonovich LJ, Simberkoff MS, Bessesen MT, Brown AC, Cummings DA, Gaydos CA, et al. N95 respirators vs medical masks for preventing influenza among health care personnel: A randomized clinical trial. JAMA. 2019;322(9):824-33. https://doi. org/10.1001/jama.2019.11645

PMid:31479137

69. Novel CPERE. The epidemiological characteristics of an outbreak of 2019 novel coronavirus diseases (COVID-19) in China. Zhonghua Liu Xing Bing Xue Za Zhi. 2020;41(2):145-51. PMid:32064853

70. Karimi A, Tabatabaei SR, Rajabnejad M, Pourmoghaddas Z, Rahimi H, Armin S, et al. An algorithmic approach to diagnosis and treatment of coronavirus disease 2019 (COVID-19) in children: Iranian expert's consensus statement. Arch Pediatr Infect Dis. 2020;8(2):e102400. https://doi.org/10.5812/ pedinfect. 102400

71. Rothan HA, Byrareddy SN. The epidemiology and pathogenesis of coronavirus disease (COVID-19) outbreak. J Autoimmun. 2020;109:102433. https://doi.org/10.1016/j.jaut.2020.102433 PMid:32113704

72. Chen S, Yang J, Yang W, Wang C, Bärnighausen T. COVID19 control in China during mass population movements at New Year. Lancet. 2020;395(10226):764-6. https://doi.org/10.1016/ s0140-6736(20)30421-9 PMid:32105609

73. Wong J, Goh QY, Tan Z, Lie SA, Tay YC, Ng SY, et al. Preparing for a COVID-19 pandemic: A review of operating room outbreak response measures in a large tertiary hospital in Singapore. Can J Anesth 2020;67(6):732-45. https://doi.org/10.1007/ s12630-020-01620-9 PMid:32162212

74. Henwood AF. Coronavirus disinfection in histopathology. J Histotechnol. 2020;43(2):102-4. https://doi.org/10.1080/014788 85.2020.1734718

PMid:32116147

75. World Health Organization. Operational Considerations for Managing COVID-19 Cases. Geneva: World Health Organization; 2020. 